\title{
ANALISIS MAKRO EKONOMI,HARGA KOMODITAS,KINERJA PASAR MODAL AMERIKA DAN PENGARUHNYA TERHADAP PASAR MODAL INDONESIA \\ ( PERIODE: MARET-JULI 2020 )
}

\author{
Noviarti \\ noviarti.arif@gmail.com \\ *) Dosen Tetap Program S1 Jurusan Manajemen Fakultas Ekonomi dan Bisnis \\ Universitas Satya Negara Indonesia
}

ABSTRACT

\begin{abstract}
This study aims to determine Macroeconomics, Community Prices, the performance of the American Capital Market and their influence on the Performance of the Indonesian Capital Market for the period March-July 2020. The sample method used is non-probability sampling method, and the sampling technique used is saturated sampling. This study uses time series data and is analyzed using the classical assumption test. In addition, multiple linear hypothesis test was also used, simultaneous $F$ test, partial t test and determination coefficient test.

From the results of the study it was found that simultaneously Macroeconomics was represented by the exchange rate, Community Prices were represented by world gold prices, the performance of the American Capital Market represented by the Dow Jones Index affected the Indonesian Capital Market represented by the IHSG in the March-July 2020 period. Partially, only the Dow Jones Index affects the Composite Stock Price Index, while the rupiah / dollar exchange rate and the world gold price have no effect on the Composite Stock Price Index (JCI) during the observation period from March to July 2020.

It can be concluded that the decline in capital market performance in developed countries also affects the Indonesian capital market. The decline in the JCI was not due to the depreciation of the Rupiah, the increase in the price of gold but was caused by negative sentiment that continued to suppress economic performance globally as a result of investor panic due to the Covid 19 pandemic continuing to spread and there was no vaccine to overcome it.
\end{abstract}

Keywords: JCI, Exchange Rate, Gold Price, Dow Jones Index

\section{A. PENDAHULUAN}

Pada awal maret kondisi perekonomian Indonesia mengalami penurunan, dimana semua sektor mulai mengalami kehancuran termasuk pasar modal Indonesia. Kemunculan pandemi Covid 19 di Indonesia menyebabkan harga saham mengalami penurunan, yaitu cyclical stock atau emiten yang sangat mudah terpengaruh dengan kondisi ekonomi dan siklus bisnis. Peristiwa penyebaran virus ini merupakan salah satu bagian dari peristiwa non ekonomi yang juga mempengaruhi kondisi pasar modal Indonesia. 


\section{Gambar 1 \\ Pergerakan Indeks Harga Saham Gabungan (IHSG) \\ Januari-Juli Tahun 2020}

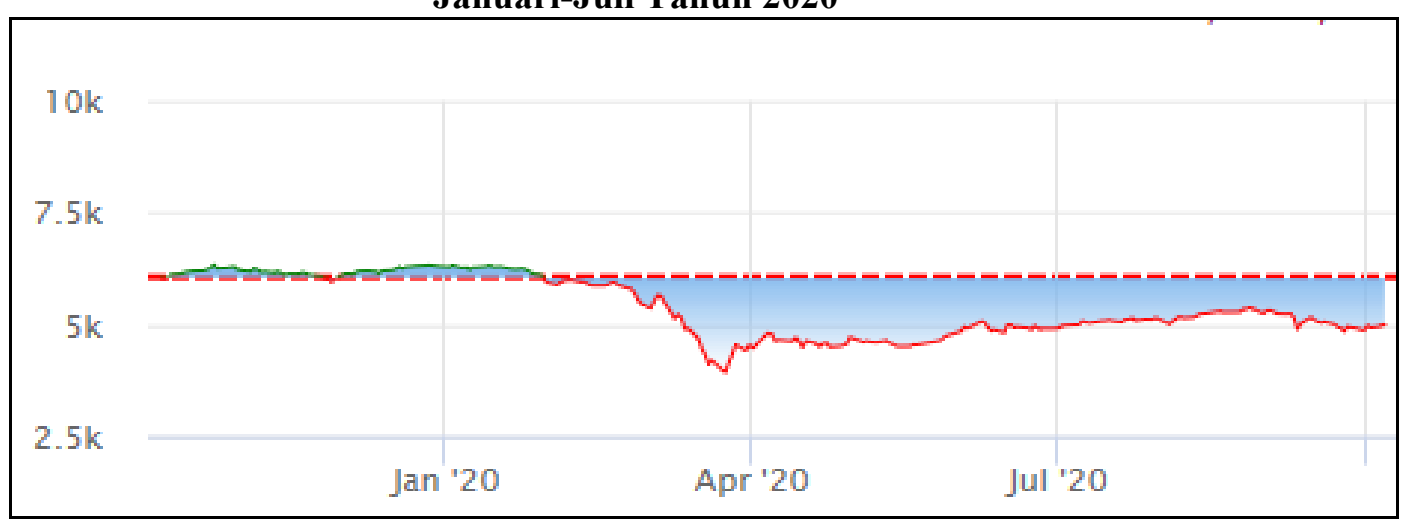

Sumber: data diolah 2020

Pada bulan Januari Indeks Harga Saham Gabungan (IHSG) sudah mulai mengalami penurunan sebagai reaksi pasar akibat Covid 19 yang melanda wuhan China pada Desember 2019 dan mulai menyebar ke negara lain pada bulan Januari 2020 termasuk Indonesia. Penurunan IHSG sebesar 3,6\% pada bulan Januari 2020, Pada bulan Februari 2020 IHSG turun sebesar 7\%, terus turun 15\% pada bulan Maret dan titik terendah dialami pada tanggal 24 Maret 2020 IHSG berada kondisi terbawah yaitu dilevel 3.937,63. Kondisi ini dikarenakan investor panik penyebaran Virus Corona semakin meluas di seluruh dunia tidak terkecuali Indonesia. Kepanikan Investor dengan melakukan penjualan saham dengan besar-besaran sehingga menyebabkan harga saham turun.

Sejak pandemi berlangsung 2 Maret hingga 16 April 2020, kurs rupiah terhadap US\$ terkoreksi sebesar $-12,4 \%$ dan IHSG telah terkoreksi $28,44 \%$. Kurs rupiah akan terus berada pada posisi rentan selama penyebaran wabah Covid-19, yang menyebabkan kepanikan di pasar global. Dan membuat dana asing kabur serta tekanan likuiditas, desakan untuk mendapatkan dolar membuat dolar lebih unggul. Pelemahan nilai tukar rupiah dikarenakan meluasnya pandemi Covid-19 di seluruh dunia, termasuk Indonesia yang menyebabkan meningkatnya risiko ketidakpastian global sehingga para investor cenderung mengalihkan dana investasinya ke safe haven asset, seperti emas, obligasi pemerintah negara maju, dan mata uang dunia, seperti dolar Amerika Serikat. Aksi tersebut mengakibatkan terjadinya arus modal keluar (capital outflow) dari negara-negara emerging market, termasuk Indonesia, yang menyebabkan terjadinya depresiasi hampir seluruh mata uang dunia terhadap dolar AS. Selama masa pandemi semester pertama tahun 2020, harga emas dunia terus menguat, sementara emas merupakan pilihan investasi yang tidak berisiko sehingga dapat dijadikan pilihan investasi. Kenaikan harga emas akan mendorong investor-investor untuk memilih berinvestasi di emas daripada di pasar modal. Sebab dengan resiko yang relative lebih rendah, emas dapat memberikan hasil imbal balik yang baik dengan kenaikan harganya. Ketika banyak investor yang mengalihkan portofolio investasinya ke dalam bentuk emas batangan, maka akan mengakibatkan turunnya indeks harga saham di negara yang bersangkutan karena aksi jual yang akan dilakukan investor.

\section{DASAR TEORITIS}

\section{PASAR MODAL}

Pasar modal juga merupakan salah satu cara bagi perusahaan dalam mencari dana dengan menjual hak kepemilikan perusahaan dalam mencari dana dengan menjual hak kepemilikan 
perusahaan kepada masyarakat. Pengertian pasar modal secara umum ialah suatu sistem keuangan yang terorganisasi, termasuk didalamnya adalah bank-bank komersial dan semua lembaga perantara dibidang keuangan, serta keseluruhan surat-surat berharga yang beredar.

Pengertian Pasar Modal menurut Azis, Mintarti, dan Nadir (2015:15): "Pasar modal adalah pasar untuk berbagai instrumen keuangan jangka panjang yang bisa diperjualbelikan baik surat utang (obligasi), ekuiti (saham), reksadana, instrumen derivatif maupun instrumen lainnya", Dan Pasar Modal menurut Hartono (2015:29):"Pasar modal merupakan sebuah sarana perusahaan untuk meningkatkan kebutuhan dana jangka panjang dengan menjual saham atau mengeluarkan objek obligasi". Dapat dikatakan bahwa pasar modal sebagai sarana untuk memperjual belikan surat utang (obligasi), ekuiti (saham), reksadana, instrumen derivatif maupun instrumen lainnya.

\section{Indeks Harga Saham Gabungan (IHSG)}

Indeks Harga Saham Gabungan atau IHSG, dalam bahasa inggris disebut juga Jakarta Composite Indexatau JSX. Composite merupakan salah satu jenis indeks yang ada di Bursa Efek Indonesia (BEI).

Jogiyanto (2015:147), menyatakan bahwa Indeks Harga Saham Gabungan merupakan angka indeks harga saham yang sudah disusun dan dihitung dengan menghasilkan trend, dimana angka indeks adalah angka yang diolah sedemikan rupa sehingga dapat digunakan untuk membandingkan kejadian yang dapat berupa perubahan harga saham dari dari waktu ke waktu. Informasi yang ditunjukkan oleh Indeks Harga Saham Gabungan setiap waktunya merupakan gambaran dari situasi pasar yang terjadi secara umum atau untuk menunjukkan apakah harga saham mengalami kenaikan atau penurunan di suatu negara tersebut. Indeks Harga Saham Gabungan mencerminkan suatu nilai yang berfungsi sebagai pengukuran kinerja suatu saham gabungan di bursa efek.

Menurut Zulbiadi Latief (2018), Indeks Harga Saham Gabungan adalah indeks untuk seluruh saham yang diperdagangkan di BEI, yang mencerminkan trend pergerakan dan nilai rata-rata keseluruhan saham dari emiten yang ada di Indonesia.

Berdasarkan definisi para ahli diatas, maka peneliti mendefiniskan Indeks Harga Saham Gabungan adalah indikator pergerakan harga semua saham yang tercatat di Bursa Efek Indonesia baik saham biasa maupun saham preferen, IHSG bisa dipakai untuk menilai situasi pasar secara umum atau mengukur apakah harga saham mengalami kenaikan atau penurunan karena IHSG melibatkan seluruh harga saham yang tercatat di Bursa Efek Indonesia.

Perhitungan Indeks Harga Saham Gabungan (IHSG) ini, kita harus menjumlahkan seluruh harga saham yang tercatat. Rumus untuk menghitung IHSG adalah sebagai berikut:

$$
\text { IHSG }=\frac{\Sigma H_{t}}{\Sigma H_{o}} \times 100 \%
$$

Dimana:

$\Sigma \mathrm{Ht}=$ Total harga saham pada waktu yang berlaku

$\Sigma \mathrm{Ho}=$ Total harga saham pada waktu dasar

\section{Faktor yang mempengaruh IHSG}

Faktor-faktor yang mempengaruhi IHSG terbagi menjadi dua, yaitu faktor yang berasal dari dalam negeri (internal) dan yang berasal dari luar negeri (eksternal). Faktor yang berasal dari dalam negeri (internal) yaitu variabel makro ekonomi. Berikut ini beberapa variabel makro ekonomi : 


\section{Produk Domestik Bruto}

Menurut Eduardus Tandelilin (2016), Produk Domestik Bruto (PDB) adalah ukuran produksi barang dan jasa total suatu negara. Pertumbuhan PDB yang cepat merupakan indikasi terjadinya pertumbuhan ekonomi. Jika pertumbuhan ekonomi membaik, maka daya beli masyarakat pun akan meningkat, dan ini merupakan kesepatan bagi perusahaan-perusahaan untuk meningkatkan penjualannya. Dengan meningkatnya penjualan perusahaan, maka kesempatan perusahaan memperoleh keuntungan juga akan semakin meningkat. Perusahaan yang memiliki laba yang baik akan meningkatkan nilai perusahaan sehingga dapat mempengaruhi peningkatan harga saham pula.

\section{Inflasi}

Menurut Eduardus Tandelilin (2015), Inflasi adalah kecenderungan terjadinya peningkatan harga produk-produk secara keseluruhan. Pengaruh inflasi terhadap adalah dengan terjadinya inflasi biaya produksi perusahaan semakin meningkat, sehingga perusahaan juga harus menaikan harga jual produk. Apabila harga jual produk naik makan penjualan akan turun karna minat konsumsi masyarakat pun menurun, sehingga akan mengurangi pendapatan yang didapat oleh perusahaan dan laba pun akan menurun. Dengan penurunan laba dapat membuat nilai perusahaan dimata investor pun menurun dan akan berdampak pada penurunan harga saham.

\section{Nilai Tukar (Kurs Rupiah)}

Menurut Sadono Sukirno (2015), kurs valuta asing atau kurs mata uang asing menunjukkan harga atau nila mata uang sesuatu negara dinyatakan dalam nilai mata uang negara lain. Kurs valuta asing juga di definisikan sebagai jumlah uang domsestik yang dibutihkan, yaitu banyaknya rupiah yang dibutuhkan, untuk memperoleh satu unit mata uang asing. Pengaruh kurs rupiah terhadap IHSG adalah jika nilai tukar rupiah meningkat maka IHSG akan turun, karena investor akan lebih memilih berinvestasi dipasar uang dibandingkan dipasar modal. Nilai tukar yang mengalami depresiasi (melemah) dapat meningkatkan harga bahan baku yang diimpor, yang akan menyebabkan perusahaan menaikan harga jual produk, dan membuat daya beli konsumen menurun. Penurunan daya beli konsumen dapat pula menurunkan pendapatan atau laba perusahaan, dan nilai perusahaan akan turun dimata investor sehingga harga saham pun menurun.

\section{Tingkat Suku Bunga SBI}

Tingkat suku bunga menurut Faris (2017) tingkat suku bunga menyatakan tingkat pembayaran atas pinjaman atau investasi, di atas perjanjian pembayaran kembali, yang dinyatakan dalam persentase yang ditetapkan Bank Indonesia dengan mengeluarkan Sertifikat Bank Indonesia. Pengaruh tingkat suku bunga terhadap IHSG adalah kenaikan suku bunga SBI akan mendorong investor untuk melakukan investasi hal ini dikarenakan perubahan suku bunga SBI juga akan mempengaruhi suku bunga deposito dan suku bunga kredit di masyarakat. kenaikan suku bunga SBI akan mendorong investor untuk mengalihkan dananya dari saham ke instrumen ini maupun ke tabungan dan deposito, karena bisa memberikan tingkat pengembalian yang lebih baik. Kondisi seperti ini akan memicu penurunan IHSG, begitu juga sebaliknya.

Faktor dari luar negeri (eksternal) yaitu harga minyak, harga mas dan indeks bursa saham negara lain (Trisnadi Wijaya,2015). Berikut ini faktor eksternal , yaitu :

1) Harga Minyak

Pengaruh harga minyak terhadap IHSG adalah apabila permintaan minyak secara global naik merupakan pertanda membaiknya pemulihan ekonomi global. Sebaliknya, turunnya permintaan minyak secara global mencerminkan melemahnya pemulihan ekonomi global. Oleh karena itu, jika 
harga minyak meningkat, ekpetasi terhadap membaiknya kinerja perusahaan di sektor tersebut akan meningkat dan otomatis harga sahamnya meningkat.

\section{2) Harga Emas}

Pengaruh harga emas terhadap IHSG adalah kenaikan harga emas akan mendorong investor untuk memilih berinvestasi di emas dari pada pasar modal. Ketika investor mengalihkan investasinya kedalam bentuk emas, maka akan menyebabkan IHSG akan menurun.

\section{3) Indeks Bursa Negara Lain}

Terintegrasinya pasar modal Indonesia dengan pasar modal lain membuat pergerakan IHSG akan dipengaruhi pergerakan pasar modal lain terutama dari negara yang memiliki perekonomian kuat.

\section{Kurs / Nilai Tukar Rupiah}

Menurut Sadono sukirno (2015), kurs valuta asing atau kurs mata uang asing merupakan harga atau nilai mata uang suatu Negara dinyatakan dalam nilai mata uang negara lain. Kurs valuta asing juga di definisikan sebagai jumlah uang domestic yang dibutuhkan yaitu banyaknya rupiah yang dibutuhkan, untuk memperoleh satu unit mata uang asing. Menurut Mahyus Ekananda (2015:168), Kurs merupakan harga suatu mata uang relatif terhadap mata uang negara lain. Kurs memainkan peranan penting dalam keputusan-keputusan pembelanjaan, karena kurs memungkinkan kita menerjemahkan harga-harga dari berbagai negara ke dalam satu bahasa yang sama.Sedangkan Menurut Murni (2015:244) kurs (exchange rate) antara dua negara adalah "kurs (exchange rate) valuta asing adalah sebagai jumlah uang domestik yang dibutuhkan untuk memperoleh satu unit mata uang asing."

Dari pengertian kurs diatas maka dapat disimpulkan, Kurs adalah Nilai tukar mata uang suatu negara dengan mata uang negara lain. Pada saat kurs rupiah terdepresiasi, maka biaya bahan baku impor atau produk yang memiliki kaitan dengan produk impor akan mengalami kenaikan. Hal ini menyebabkan biaya produksi meningkat dan laba perusahaan berpotensi menurun.

\section{Faktor yang mempengaruh IHSG}

Faktor-faktor yang mempengaruhi IHSG terbagi menjadi dua, yaitu faktor yang berasal dari dalam negeri (internal) dan yang berasal dari luar negeri (eksternal). Faktor yang berasal dari dalam negeri (internal) yaitu variabel makro ekonomi. Berikut ini beberapa variabel makro ekonomi :

\section{1) Produk Domestik Bruto}

Menurut Eduardus Tandelilin (2016), Produk Domestik Bruto (PDB) adalah ukuran produksi barang dan jasa total suatu negara. Pertumbuhan PDB yang cepat merupakan indikasi terjadinya pertumbuhan ekonomi. Jika pertumbuhan ekonomi membaik, maka daya beli masyarakat pun akan meningkat, dan ini merupakan kesepatan bagi perusahaan-perusahaan untuk meningkatkan penjualannya. Dengan meningkatnya penjualan perusahaan, maka kesempatan perusahaan memperoleh keuntungan juga akan semakin meningkat. Perusahaan yang memiliki laba yang baik akan meningkatkan nilai perusahaan sehingga dapat mempengaruhi peningkatan harga saham pula.

\section{2) Inflasi}

Menurut Eduardus Tandelilin (2015), Inflasi adalah kecenderungan terjadinya peningkatan harga produk-produk secara keseluruhan. Pengaruh inflasi terhadap adalah dengan terjadinya inflasi biaya produksi perusahaan semakin meningkat, sehingga perusahaan juga harus menaikan harga jual produk. Apabila harga jual produk naik makan penjualan akan turun karna minat konsumsi masyarakat pun menurun, sehingga akan mengurangi pendapatan yang didapat oleh perusahaan dan laba pun akan menurun. Dengan penurunan laba dapat membuat nilai perusahaan dimata investor pun menurun dan akan berdampak pada penurunan harga saham. 


\section{3) Nilai Tukar (Kurs Rupiah)}

Menurut Sadono Sukirno (2015), kurs valuta asing atau kurs mata uang asing menunjukkan harga atau nila mata uang sesuatu negara dinyatakan dalam nilai mata uang negara lain. Kurs valuta asing juga di definisikan sebagai jumlah uang domsestik yang dibutihkan, yaitu banyaknya rupiah yang dibutuhkan, untuk memperoleh satu unit mata uang asing. Pengaruh kurs rupiah terhadap IHSG adalah jika nilai tukar rupiah meningkat maka IHSG akan turun, karena investor akan lebih memilih berinvestasi dipasar uang dibandingkan dipasar modal. Nilai tukar yang mengalami depresiasi (melemah) dapat meningkatkan harga bahan baku yang diimpor, yang akan menyebabkan perusahaan menaikan harga jual produk, dan membuat daya beli konsumen menurun. Penurunan daya beli konsumen dapat pula menurunkan pendapatan atau laba perusahaan, dan nilai perusahaan akan turun dimata investor sehingga harga saham pun menurun.

\section{4) Tingkat Suku Bunga SBI}

Tingkat suku bunga menurut Faris (2017) tingkat suku bunga menyatakan tingkat pembayaran atas pinjaman atau investasi, di atas perjanjian pembayaran kembali, yang dinyatakan dalam persentase yang ditetapkan Bank Indonesia dengan mengeluarkan Sertifikat Bank Indonesia. Pengaruh tingkat suku bunga terhadap IHSG adalah kenaikan suku bunga SBI akan mendorong investor untuk melakukan investasi hal ini dikarenakan perubahan suku bunga SBI juga akan mempengaruhi suku bunga deposito dan suku bunga kredit di masyarakat. kenaikan suku bunga SBI akan mendorong investor untuk mengalihkan dananya dari saham ke instrumen ini maupun ke tabungan dan deposito, karena bisa memberikan tingkat pengembalian yang lebih baik. Kondisi seperti ini akan memicu penurunan IHSG, begitu juga sebaliknya.

Faktor dari luar negeri (eksternal) yaitu harga minyak, harga mas dan indeks bursa saham negara lain (Trisnadi Wijaya,2015). Berikut ini faktor eksternal, yaitu :

1) Harga Minyak

Pengaruh harga minyak terhadap IHSG adalah apabila permintaan minyak secara global naik merupakan pertanda membaiknya pemulihan ekonomi global. Sebaliknya, turunnya permintaan minyak secara global mencerminkan melemahnya pemulihan ekonomi global. Oleh karena itu, jika harga minyak meningkat, ekpetasi terhadap membaiknya kinerja perusahaan di sektor tersebut akan meningkat dan otomatis harga sahamnya meningkat.

2) Harga Emas

Pengaruh harga emas terhadap IHSG adalah kenaikan harga emas akan mendorong investor untuk memilih berinvestasi di emas dari pada pasar modal. Ketika investor mengalihkan investasinya kedalam bentuk emas, maka akan menyebabkan IHSG akan menurun.

3) Indeks Bursa Negara Lain

Terintegrasinya pasar modal Indonesia dengan pasar modal lain membuat pergerakan IHSG akan dipengaruhi pergerakan pasar modal lain terutama dari negara yang memiliki perekonomian kuat.

\section{Kurs / Nilai Tukar Rupiah \\ Definisi Kurs}

Menurut Mahyus Ekananda (2015:168), Kurs merupakan harga suatu mata uang relatif terhadap mata uang negara lain. Kurs memainkan peranan penting dalam keputusankeputusan pembelanjaan, karena kurs memungkinkan kita menerjemahkan harga-harga dari berbagai negara ke dalam satu bahasa yang sama. Menurut Sadono sukirno (2015), kurs valuta asing atau kurs mata uang asing menunjukan harga atau nilai mata uang suatu Negara dinyatakan dalam nilai mata uang negara lain. Kurs valuta asing juga di definisikan sebagai jumlah uang domestic yang dibutuhkan yaitu banyaknya rupiah yang dibutuhkan, untuk memperoleh satu unit mata uang asing. 
Menurut Murni (2015:244) kurs (exchange rate) antara dua negara adalah "kurs (exchange rate) valuta asing adalah sebagai jumlah uang domestik yang dibutuhkan untuk memperoleh satu unit mata uang asing." Berdasarkan definisi menurut para ahli di atas, maka peneliti mendefinisikan Kurs adalah Nilai tukar suatu mata uang dengan mata uang lainnya, kurs atau nilai tukar biasanya digunakan dalam transaksi yang melibatkan dua Negara atau lebih.

Perubahan pada kurs akan mempengaruhi tingkat kompetitif suatu perusahaan, kemudian akan mempengaruhi produk perusahahaan yang berdampak pada harga saham suatu perusahaan. Pada saat kurs rupiah terdepresiasi, maka biaya bahan baku impor atau produk yang memiliki kaitan dengan produk impor akan mengalami kenaikan. Hal ini menyebabkan biaya produksi meningkat dan laba perusahaan menjadi turun.

\section{Sistem Nilai Tukar Rupiah (kurs)}

Kebijakan-kebijakan pemerintah mempengaruhi nilai tukar, yang kemudian mempengaruhi pasar keuangan dan perekonomian. Kebijakan sistem nilai tukar dapat diklasifikasikan menuerut seberapa jauh nilai tukar dikendalikan oleh pemerintah.

\section{Faktor yang mempengaruhi Kurs/ Nilai Tukar Rupiah}

Faktor-faktor dasar yang mempengaruhi perubahan kurs di pasar valuta asing sesungguhnya banyak dikemukakan para ahli . namun hal-hal tersebut masih dipandang belum konkrit dan masih terdapat inkonsistensi diantara factor yang diajukan oleh satu bidang ahli dibandingkan dengan yang lain.

Pada dasarnya , Madura dan Fox (2016:108) berpendapat bahwa terdapat 3 (tiga) faktor utama yang mempengaruhi pergerakan nilai tukar yaitu :

1. Faktor Fundamental

Faktor Fundamental berkaitan dengan indikator seperti inflasi, suku bunga, perbedaan relative pendapatan antar Negara, ekspetasi pasar dan intervensi bank sentral.

2. Faktor Teknis

Faktor teknis berkaitan dengan kondisi permintaan dan penawaran devisa ada saat tertentu. Apabila ada kelebihan permintaan sementara penawaran tetap, maka harga valuta asing akan terapresiasi. Sebaliknya apabila ada kekurangan permintaan sementara penawaran tetap, maka nilai tukar valuta asing akan terdepresiasi.

3. Sentimen Pasar

Sentimen Pasar lebih banyak disebabkan oleh rumor atau berita politik yang bersifat insidentil, yang dapat mendorong harga valuta asing naik atau turun secara tajam dalam jangka pendek. Apabila rumor atau berita sudah berlalu, maka nilai tukar akan kembali normal. Nilai tukar rupiah (kurs) yang dapat berubah disebabkan dalam permintaan dan penawaran valuta asing.

Secara umum rumus untuk menghitung jumlah konversi mata uang adalah:

$$
\text { Uang Rp }=\frac{\text { Kurs Rp }}{\text { USD }} \times \text { Uang USD }
$$

\section{Dimana :}

Uang Rp = Nilai mata uang dalam rupiah

Uang USD = Nilai mata uang dalam dolar amerika

Kurs Rp/USD = Nilai tukar rupiah terhadap dolar amerika

\section{Jenis Nilai Tukar Mata Uang}

Menurut Iswanto (2016) nilai tukar mata uang dibagi menjadi dua jenis yaitu:

a.Kurs riil adalah harga relatif dari barang-barang diantara dua negara yaitu suatu tingkat yang menyatakan dimana suatu negara bisa memperdagangkan barang dari suatu negara dengan barang negara lain atau disebut juga term of trade.

b.kurs nominal merupakan harga relatif dari mata uang dua negara.

\section{Perubahan Nilai Tukar Rupiah}


Naik turunnya nilai tukar mata uang atau kurs valuta asing bisa terjadi dengan berbagai cara, yakni bisa dengan cara dilakukan secara resmi oleh pemerintah suatu negara yang menganut sistem managed floating exchange rate atau bisa juga karena tarik menariknya kekuatan-kekuatan permintaan dan penawaran di dalam pasar (market mechanism) dan lazimnya perubahan nilai tukar mata uang tersebut bisa terjadi karena empat hal, yaitu:

1) Depresiasi (depreciation), yaitu penurunan harga mata uang nasional terhadap berbagai mata uang asing lainnya, yang terjadi karena tarik menariknya kekuatan-kekuatan supply dan demand di dalam pasar (market mechanism).

2) Apresiasi (appreciation), yaitu peningkatan harga mata uang nasional terhadap berbagai mata uang asing lainnya, yang terjadi karena tarik menariknya kekuatan-kekuatan supply dan demand di dalam pasar (market mechanism).

3) Devaluasi (devaluation), yaitu penurunan harga mata uang nasional terhadap berbagai mata uang asing lainnya yang dilakukan secara resmi oleh pemerintah suatu negara.

4) Revaluasi (revaluation), yaitu peningkatan harga mata uang nasional terhadap berbagai mata uang asing lainnya yang dilakukan secara resmi oleh pemerintah suatu negara. Metode penghitungan kurs tengah yang umum dipakai Bank Indonesia adalah dengan menjumlahkan kurs jual dan kurs beli yang kemudian dibagi dengan dua. Sehingga nampak rumus kurs tengah .

\section{Harga Emas}

\section{Definisi Harga Emas}

Menurut (Sunariyah,2015) Emas merupakan salah satu bentuk investasi yang cenderung bebas resiko. Emas banyak dipilih sebagai salah satu bentuk investasi karena nilainya cenderung stabil dan naik. Sangat jarang sekali harga emas turun. Dan lagi, emas adalah alat yang dapat digunakan untuk menangkal inflasi yang kerap terjadi setiap tahunnya. Ketika akan berinvestasi, investor akan memilih investasi yang memiliki tingkat imbal balik tinggi dengan resiko tertentu atau tingkat imbal balik tertentu dengan resiko yang rendah. Investasi di pasar saham tentunya lebih berisiko daripada berinvestasi di emas, karena tingkat pengembaliannya yang secara umum relatif lebih tinggi dari emas (www.investopedia.com).

Menurut (Mariani, 2017) Bentuk penggunaan emas dalam bidang moneter lazimnya berupa batangan emas dalam berbagai satuan berat gram sampai kilogram .

Berdasarkan definisi menurut para ahli di atas, maka peneliti mendefinisikan emas adalah salah satu jenis logam mulia yang dapat dijadikan sebagai alat investasi dengan tingkat timbal balik yang tinggi dang resiko yang rendah dan memilki nilai moneter absolut tersendiri terhadap mata uang di seluruh dunia.

\section{Faktor-faktor yang mempengaruhi Harga Emas}

Faktor-faktor yang mempengaruhi harga emas menurut (Abdullah, 2015) adalah:

a) Inflasi yang Meningkat Melebihi Prediksi

Tingkat inflasi biasanya akan mempengaruhi kebijakan ekonomi di setiap negara. Tingkat inflasi yang sudah diprediksi dalam bentuk persen akan dijadikan acuan untuk menetapkan tingkat suku bunga di negara tersebut.

b) Kericuhan Finansial

Krisis moneter pada tahun 1998 dan 2008 termasuk kedalam kericuhan atau kepanikan finansial. Ini merupakan faktor yang bisa membuat harga emas tiba-tiba melonjak tidak terkendali.

c) Kenaikan Harga Minyak yang Siginifikan

Ketika harga minyak mentah dunia naik secara signifikan, maka harga emas pun ikut mengalami kenaikan. Jika invasi ini terus terusan terjadi, maka kenaikan harga minyak dunia tidak dapat dielak lagi.

d) Permintaan Emas

Harga emas akan terus naik jika permintaan emas dunia yg terus naik 
berbanding terbalik dengan pasokan emas yang ada. Inilah yang dinamakan sebagai hukum supply demand.

e) Kondisi Politik di Dunia

Ketidakpastian ekonomi adalah akibat dari suhu politik dunia yang tinggi karena ketegangan yang terjadi antar negara-negara di dunia. Harga emas juga turut terpengaruhi karena faktor yang satu ini.

f) Perubahan kurs

Melemahnya kurs dollar AS dapat mendorong kenaikan harga emas dunia. Ketika tingkat suku bunga naik, ada usaha yang besar untuk tetap menyimpan uang pada deposito ketimbang emas yang tidak menghasilkan bunga (non interest-bearing). Ini akan menimbulkan tekanan pada harga emas. Sebaliknya, ketika suku bunga turun, harga emas akan cenderung naik.

\section{Indeks Dow Jones}

Menurut (Virby ,2017) Dow Jones Industrial Average (DJIA), atau hanya Dow adalah Indeks pasar saham yang menunjukan bagaimana 30 perusahaan besar milik public yang berbasis di Amerika Serkat telah diperdagangkan selama sesi perdangan standar di pasar saham.

Menurut (Martin, 2016) Indeks Nilai Dow tidak berarti artimatika berbobot dan tidak mewakili kapitalisasi pasar dan perusahaan komponennya, tetapi lebih menggambarkan harga total satu bagian untuk setiap perusahaan komponen. Jumlah ini dikoreksi oleh factor-faktor yang berubah setiap kali salah satu dari saham komponen memiliki stock split atau dividen saham, menghasilkan nilai yang konsisten untuk Indeks.

Menurut (Harfikawat ,2016) Indeks Dow Jones merupakan Indeks rata-rata saham terbesar di dunia, oleh karena itu pergerakan indeks dow jones dapat mempengaruhi hampir seluruh indeks saham dunia termasuk IHSG. Pengaruh Indeks Dow Jones akan menaikan IHSG di BEI , hal ini disebabkan oleh adanya sentiment positif dari para investor terhadap kondisi ekonomi dunia.

\section{METODE PENELITIAN}

\section{Hipotesis Penelitian :}

Hipotesis Secara Simultan :

Ho1: $\beta \leq 0=$ Kurs (Nilai tukar rupiah), Harga Emas dan Indeks Dow Jones diduga tidak berpengaruh terhadap Indeks Harga Saham Gabungan (IHSG).

Ha1: $\beta>0=$ Kurs (Nilai tukar rupiah), Harga Emas dan Indeks Dow Jones diduga berpengaruh terhadap Indeks Harga Saham Gabungan (IHSG).

Hipotesis Secara Parsial :

Ho2: $\beta \leq 0=$ Kurs (Nilai tukar rupiah) diduga tidak berpengaruh terhadap Indeks Harga Saham Gabungan (IHSG).

Ha2: $\beta>0=$ Kurs (Nilai tukar rupiah) diduga berpengaruh Indeks Harga Saham Gabungan (IHSG).

Ho3: $\beta \leq 0=$ Harga Emas diduga tidak berpengaruh terhadap Indeks Harga Saham Gabungan (IHSG).

Ha3: $\beta>0=$ Harga Emas diduga berpengaruh terhadap Indeks Harga Saham Gabungan (IHSG).

Ho4: $\beta \leq 0$ = Indeks Dow Jones diduga tidak berpengaruh terhadap Indeks Harga Saham Gabungan (IHSG).

Ha4: $\beta>0$ = Indeks Dow Jones diduga berpengaruh terhadap Indeks Harga Saham Gabungan (IHSG).

\section{Variabel Penelitian}

Variabel Terikat (Dependent variable)

Variabel terikat adalah variabel yang diduga sebagai akibat atau variabel yang dipengaruhi oleh variabel yang mendahuluinya, yakni variabel bebas. Variabel terikat (Y) dalam penelitian ini adalah Indeks Harga Saham Gabungan, definisi IHSG menurut Jogiyanto (2015:147), merupakan 
angka indeks harga saham yang sudah disusun dan dihitung dengan menghasilkan trend, dimana angka indeks adalah angka yang diolah sedemikan rupa sehingga dapat digunakan untuk membandingkan kejadian yang dapat berupa perubahan harga saham dari dari waktu ke waktu.

Indeks Harga Saham Gabungan (IHSG) Indeks Harga Saham Gabungan atau IHSG (composite stock price index), yaitu indeks yang menggunakan semua saham yang tercatat sebagai komponen perhitungan indeks. Perhitungan untuk Indeks Harga Saham Gabungan yaitu :

\section{Indeks $=\underline{\text { Nilai Pasar }} \times 100$}

Nilai Dasar

Keterangan :

Nilai Pasar $=$ Kumulatif jumlah saham hari ini dikali harga pasar hari ini atau disebut dengan kapitalisasi pasar

Nilai Dasar $=$ Nilai yang dihitung berdasarkan harga perdana dari masing-

masing saham atau berdasarkan harga yang telah dikoreksi jika perusahaan telah melakukan kegiatan yang menyebabkan jumlah saham yang tercatat di bursa berubah.

\section{Variabel Bebas(Independen Variable)}

Variabel bebas adalah variabel yang menentukan atau yang mempengaruhi adanya variabel yang lain . Variabel bebas yang digunakan dalam penelitian ini berupa:

\section{a) Kurs ( Nilai Tukar Rupiah terhadap Dollar )}

Menurut Mahyus Ekananda (2015:168), Kurs merupakan harga suatu mata uang relatif terhadap mata uang negara lain. Kurs memainkan peranan penting dalam keputusankeputusan pembelanjaan, karena kurs memungkinkan kita menerjemahkan harga-harga dari berbagai negara ke dalam satu bahasa yang sama. Metode penghitungan kurs tengah yang umum dipakai Bank Indonesia adalah dengan menjumlahkan kurs jual dan kurs beli yang kemudian dibagi dengan dua.

\section{Kurs Tengah $=\underline{\text { Kurs Jual }- \text { Kurs Beli }}$}

\section{b) Harga Emas}

Menurut Henny Mariani (2017) Emas digunakan sebagai standar keuangan di banyak negara dan juga sebagai alat tukar yang relatif abadi, dan diterima di semua negara di dunia. Penggunaan emas dalam bidang moneter dan keuangan berdasarkan nilai moneter absolut dari emas itu sendiri terhadap berbagai mata uang di seluruh dunia, meskipun secara resmi di bursa komoditas dunia, harga emas dicantumkan dalam mata uang dolar Amerika

c) Indeks Dow Jones

Menurut (Virby ,2017) Dow Jones Industrial Average (DJIA), atau hanya Dow adalah Indeks pasar saham yang menunjukan bagaimana 30 perusahaan besar milik public yang berbasis di Amerika Serikat telah diperdagangkan selama sesi perdangan standar di pasar saham. Dow Jones Industrial Average dihitung dengan menggunakan rumus sebagai berikut :

$$
\text { Indeks }=\frac{\sum P}{N d}
$$

Keterangan :

$\mathrm{P}=$ Harga Saham

$\mathrm{Nd}=$ Nilai dasar, yaitu nilai yang dibentuk berdasarkan jumlah saham yang tercatat. Jadi, 30 saham perusahaan yang telah masuk ke indeks dow jones di asumsikan memiliki bobot yang sama. 


\section{Populasi dan Sampel \\ Populasi}

Menurut Sanusi (2017) Populasi adalah kumpulan elemen yang menunjukan ciri-ciri tertentu yang dapat digunakan untuk membuat kesimpulan. Populasi didalam penelitian ini adalah Seluruh data Indeks Harga Saham Gabungan yang berada di Bursa Efek Indonesia, Kurs Dollar terhadap rupiah, Harga emas, dan Indeks Dow Jones selama periode penelitian dari bulan Maret sampai dengan bulan Juli 2020 dengan jumlah data yaitu 99 data yang diambil dari data harian.

\section{Sampel}

Sampel adalah bagian dari elemen-elemen popullasi dimana elemen ini merupakan subjek pengukuran yang dilakukan (Anwar Sanusi, 2017). Sampel yang diambil dalam penelitian ini adalah data Indeks Harga Saham Gabungan, kurs dollar terhadap rupia, harga emas dan indeks dow Jones yang dibatasi selama periode Maret - Juli 2020. Metode Sampel yang digunakan adalah dengan menggunakan Metode non probability sampling, teknik sampling yang digunakan adalah sampling jenuh yaitu teknik penentuan sampel bila semua anggota populasi digunakan sebagai sampel.

\section{TEKNIK ANALISIS DATA}

Penelitian ini menggunakan data time series dan dianalisis dengan uji asumsi klasik yaitu uji normalitas ,uji autokorelasi,uji multikolinearitas, dan uji heteroskedastisitas. Tujuan asumsi klasik agar diperolehnya model regresi yang bersifat BLUE(Best Linear Unbiased Estimator). Selain itu juga digunakan uji hipotesis linear berganda,uji $F$ secara simultan,uji $t$ untuk parsial dan uji koefiien determinasi.

\section{UJI ASUMSI KLASIK}

\section{Uji normalitas}

- Dengan membandingkan nilai signifikan yang dicapai dengan taraf signifikansi yang sudah ditentukan yaitu 0,05 . Distribusi data dikatakan normal jika signifikansi $(p)>0,05$ dan data terdistribusi tidak normal apabila nilai signifikansi (p) , 0,05. Berikut ini merupakan hasil uji normalitas dengan Kolmogorov-Smirnov adalah sebagai berikut:

\section{Tabel 1}

Hasil Uji Normalitas Data

One-Sample Kolmogorov-Smirnov Test

\begin{tabular}{|l|l|r|}
\hline \multicolumn{2}{|c|}{} & Unstandardized Residual \\
\hline $\mathrm{N}$ & Mean & 81 \\
\hline \multirow{2}{*}{ Normal Parameters } & .,b & 142.10000000 \\
\cline { 2 - 3 } & Std. Deviation & .071 \\
\hline \multirow{2}{*}{ Most Extreme Differences } & Absolute & .071 \\
\cline { 2 - 3 } & Positive & -.038 \\
\cline { 2 - 3 } & Negative & .071 \\
\hline Test Statistic & & $.200^{\text {c,d }}$ \\
\hline Asymp. Sig. (2-tailed) & &
\end{tabular}

a. Test distribution is Normal. Sumber : Hasil pengolahan data

b. Calculated from data.

c. Lilliefors Significance Correction.

d. This is a lower bound of the true significance.

Hasil pengujian Kolmogorov-Smirnov diketahui bahwa hasil menunjukan angka sebesar 0,200 yang berarti bahwa dengan nilai melebihi taraf signifikan yang telah di tentukan yaitu 0,05 sehingga menunjukan data-data dalam penelitian ini terdistribusi normal. 


\section{Uji Normalitas Residual}

Dalam pengujian normalitas residual untuk mendeteksi apakah data berdistribusi normal atau tidak mengunakan cara Uji Normal p-plot of regression standardized residual dari variabel terikat, dimana :

- Jika data menyebar di sekitar garis diagonal dan mengikuti arah garis diagonal, maka model regresi memenuhi asumsi normalitas.

- Jika data menyebar jauh dari garis diagonal dan atau tidak mengikuti garis diagonal, maka model regresi tidak memenuhi asumsi normalitas.

Berikut gambar hasil pengujian Normal p-plot of regression standardized residual:

\section{Gambar 2}

Hasil Uji Normalitas residual

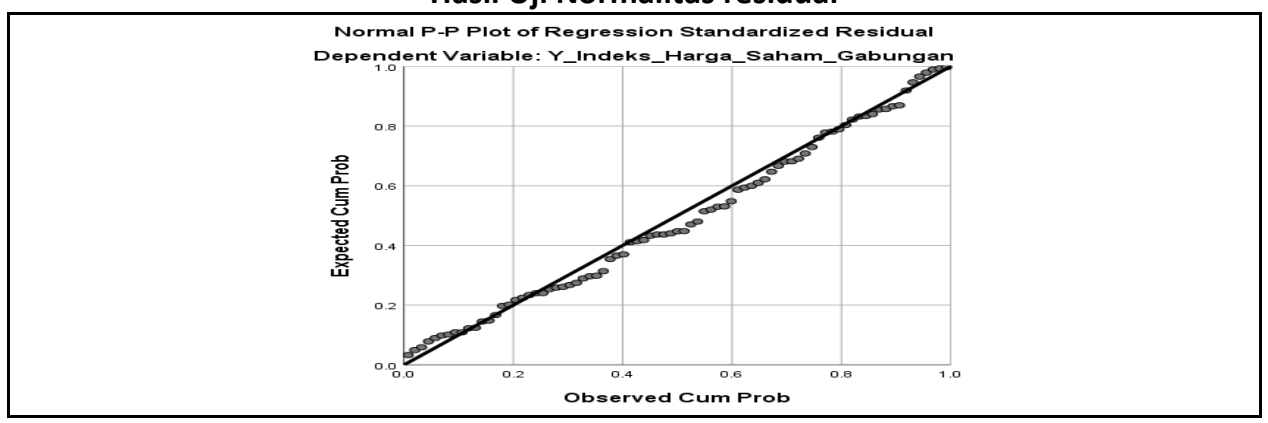

Sumber: data diolah 2020

Dari gambar grafik di atas dapat diketahui bahwa titik-titik menyebar sekitar garis dan mengikuti garis diagonal, maka nilai residual tersebut terdistribusi secara normal.

\section{Uji Multikolinearitas}

Uji multikolinieritas ini bertujuan untuk menguji apakah model regresi ditemukan adanya hubungan antara variabel bebas. Menurut Ghozali (2011), model regresi yang baik seharusnya tidak memiliki korelasi diantara variabel independen.

Ada tidaknya multikolinearitas dalam model regresi dilihat dari Variance Inflation Factor (VIF) dan nilai Tolerance (T). Jika nilai VIF $\leq 10$ dan nilai $\mathrm{T} \geq 0,10$, maka tidak terjadi multikolinearitas. Untuk menguji multikolinieritas dapat dilihat dari output SPSS pada nilai Tolerance (T) dan nilai VIF (Variance Inflation Faktor)sebagai berikut:

Tabel 2

Hasil Uji Multikolinearitas

Coefficients $^{\mathrm{a}}$

\begin{tabular}{|l|l|r|r|}
\hline \multicolumn{2}{|c|}{} & \multicolumn{2}{|c|}{ Collinearity Statistics } \\
\cline { 2 - 4 } Model & Tolerance & VIF \\
\hline \multirow{3}{*}{1} & X1_Kurs & .138 & 7.243 \\
\cline { 2 - 4 } & X2_Harga_Emas & .411 & 2.434 \\
\cline { 2 - 4 } & X3_Indeks_Dow_Jones & .190 & 5.257 \\
\hline
\end{tabular}

a. Dependent Variable: Y_Indeks_Harga_Saham_Gabungan

sumber : Data diolahi 2020

Dari tabel diatas dapat diketahui bahwa nilai Variance Inflaction Factor (VIF) dari ke tiga variable bebas yaitu, Kurs, Harga Emas, Dan Indeks Dow Jones masing-masing nilai VIF nya kurang dari 10 dan dilihat dari nilai Tolerance masing-masing diatas 0.10 sehingga dapat disimpulkan bahwa antar variabel Kurs, Harga Emas dan Indeks Dow Jones tidak memiliki hubungan antar variabel atau tidak ada masalah Multikolinieritas. 


\section{Uji Heteroskedastisitas dengan Uji Scatterplot}

Pengujian ini bertujuan untuk menguji apakah dalam model regresi terjadi ketidaksamaan variance dari residual satu pengamatan ke pengamatan yang lain. Berikut cara untuk mendeteksi ada tidaknya heteroskedastisitas yaitu dengan melihat grafik Scatter plot antara nilai prediksi variabel terikat (dependen) yaitu SRESID dengan residualnya ZPRED. Deteksi ada tidaknya heteroskedastisitas dapat dilakukan dengan melihat ada tidaknya pola tertentu pada grafik scatterplot. Berikut ini merupakan hasil uji heteroskedastisitas grafik Scatterplot .

\section{Gambar 3}

\section{Grafik Scatterplot}

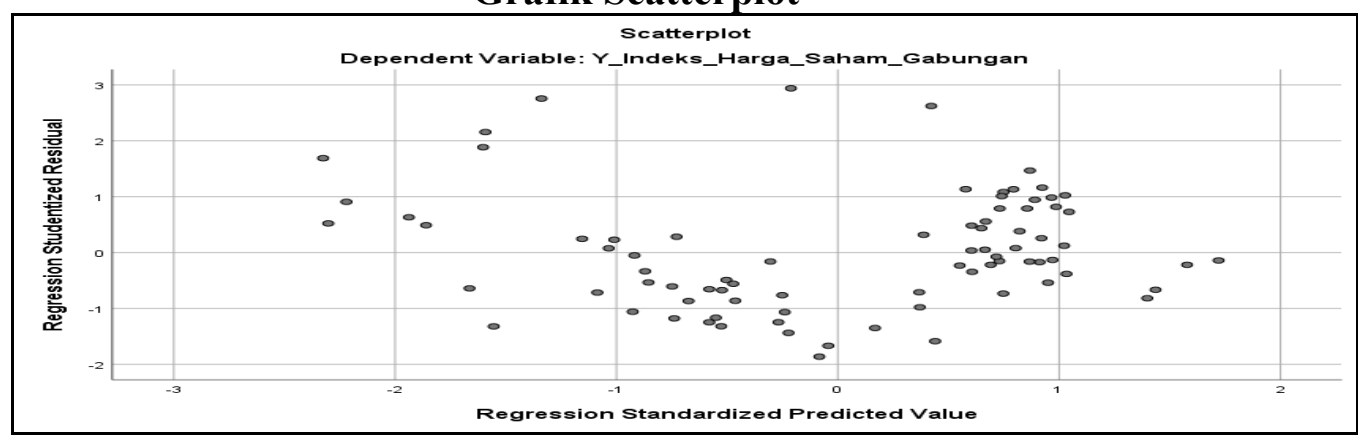

Sumber: Data diolah 2020

Dari gambar 4.2 di atas dapat diketahui bahwa titik-titik tidak membentuk pola yang jelas, dantitik-titik menyebar diatas dan dibawah angka 0 pada sumbu Y, maka ini menunjukkan tidak terjadi heteroskedastisitas.

\section{Uji Autokorelasi}

Autokorelasi merupakan korelasi antara anggota observasi yang disusun menurut waktu atau tempat. Pengujian autokorelasi yang digunakan dalam penelitian ini menggunakan uji Durbin-Watson. Dimana Hasil perhitungan Durbin Watson harus lebih besar dibandingkan dengan nilai dU tabel durbin Watson, dan juga harus lebih kecil dari 4-dU (4 dikurang nilai d U pada tabel durbin Watson). Berikut ini merupakan hasil uji autokorelasi.

Tabel 3

Hasil Uji Autokorelasi

\begin{tabular}{|c|r|r|r|r|r|}
\hline \multicolumn{7}{|c|}{$\begin{array}{l}\text { Model Summary } \\
\text { el }\end{array}$} & R & R Square & $\begin{array}{c}\text { Adjusted R } \\
\text { Square }\end{array}$ & $\begin{array}{c}\text { Std. Error of } \\
\text { the Estimate }\end{array}$ & $\begin{array}{r}\text { Durbin- } \\
\text { Watson }\end{array}$ \\
\hline 1 & $.690^{\text {a }}$ & .476 & .455 & 75.64927 & 1.929 \\
\hline $\begin{array}{l}\text { a. Predictors: (Constant), Lag_X3_Indeks_Dow_Jones, Lag_X2_Harga_Emas, } \\
\text { Lag_X1_Kurs } \\
\text { b. Dependent Variable: Lag_Y_Indeks_Harga_Saham_Gabungan }\end{array}$ \\
\hline
\end{tabular}

Sumber : Data di Olah 2020

Dari tabel 3 diatas menunjukan nilai Durbin Watson (d) Sebesar 1.929. Dan untuk menguji apakah terjadi autokorelasi atau tidak adalah dengan mencari nilai $\mathrm{d} \mathrm{L}$ dan $\mathrm{d} U$ yang dapat diketahui dan dilihat dari tabel Durbin Watson, dan diketahui nilai $\mathrm{n}=81, \mathrm{k}=3, \mathrm{~d} \mathrm{~L}=$ 1.5632 dan $\mathrm{d} U=1.7164$. Maka dari itu dapat disimpulkan bahwa $\mathrm{d}>\mathrm{d} \mathrm{L}=1.929>1.7164$ maka hasilnya adalah terjadi autokorelasi yang positif. 


\section{Persamaan Regresi Linier Berganda}

Model ini digunakan untuk mengetahui pengaruh variabel bebas terhadap variabel terikat dengan persamaan sebagai berikut :

$$
\mathbf{Y}=\mathbf{a}+{ }_{b 1} \mathbf{X}^{1}+{ }_{b 2} \mathbf{X}^{2}+{ }_{b 3} \mathbf{X}^{3}+{ }_{b 4} \mathbf{X}^{4}+\mathbf{e}
$$

Berdasarkan hasil pada tabel Coefficients tersebut dapat disusun persamaan regresi linier berganda sebagai berikut :

Tabel 4

Hasil Uji Persamaan Regresi

Coefficients $^{\mathrm{a}}$

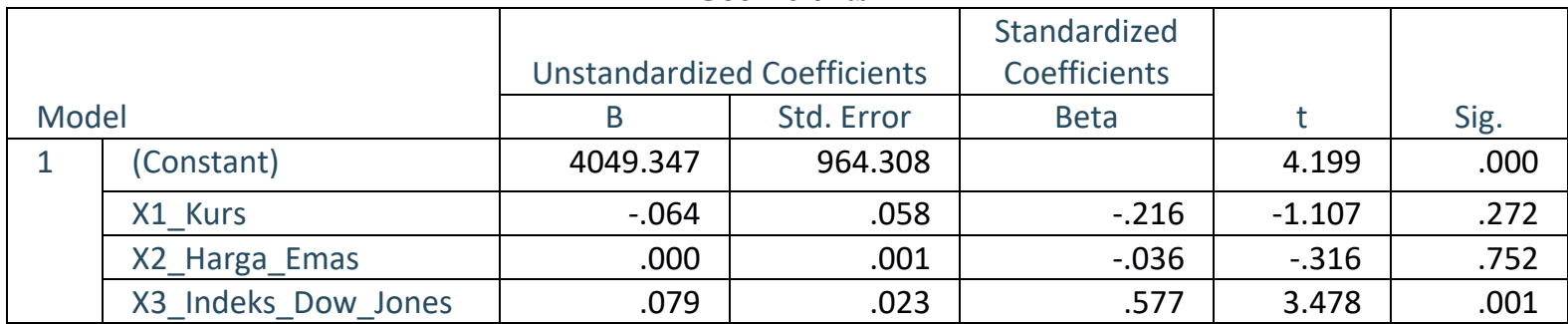

a. Dependent Variable: Y_Indeks_Harga_Saham_Gabungan

Sumber : Data diolah 2020

\section{IHSG $=4.049,347-0,064 X_{1}+0,000 X_{2}+0,079 X_{3}$}

1) Koefisien $X_{1}=-0,064$

Jika nilai variable Kurs rupiah (X1) sebesar 1 satuan , sementara Harga Emas (X2) dan Indeks Dow Jones (X3) dianggap tetap, maka akan mempengaruhi penurunan variable IHSG sebesar 0,064 .

2) Koefisien $X_{2}=0,000$

Jika nilai variable Harga Emas (X2) mengalami kenaikan sebesar 1 satuan, sementara Kurs (X1) dan Indeks Dow Jones (X3) dianggap tetap, maka nilai variable IHSG 0,000

3) Koefisien $X_{3}=0,079$

Jika nilai variable Indeks Dow Jones (X3) Mengalami kenaikan sebesar 1 satuan, sementara Kurs (X1) dan Harga Emas (X2) dianggap tetap, maka akan mempengaruhi kenaikan nilai variable IHSG sebesar 0,079

\section{. Uji Simultan (Uji F)}

Tabel 5

Hasil Uji F

\begin{tabular}{|l|l|r|r|r|r|c|}
\hline \multicolumn{7}{|c|}{ ANOVA $^{\text {a }}$} \\
\hline \multirow{3}{*}{ Model } & $\begin{array}{r}\text { Sum of } \\
\text { Squares }\end{array}$ & df & $\begin{array}{c}\text { Mean } \\
\text { Square }\end{array}$ & F & Sig. \\
\hline 1 & $\begin{array}{l}\text { Regressio } \\
\mathrm{n}\end{array}$ & $\begin{array}{r}2393545.48 \\
4\end{array}$ & 3 & 797848.495 & 38.031 & $.000^{\mathrm{b}}$ \\
\cline { 2 - 7 } & Residual & 1615395.09 & 77 & 20979.157 & & \\
& 6 & & & & \\
\cline { 2 - 7 } & Total & 4008940.58 & 80 & & & \\
& 0
\end{tabular}

Sumber : Data diolah 2020 
Hasil pengujian Uji $F$ menunjukan nilai signifikan yang diperoleh adalah 0,000 berarti lebih kecil dari tingkat signifikan 0,05.Karena nilai sig $<0,05$ maka H1 diterima, Sehingga dapat disimpulkan bahwa Kurs, Harga Emas, dan Indeks Dow Jones secara simultan berpengaruh terhadap IHSG.

\section{Uji Parsial (Uji t )}

Berikut ini merupakan hasil Uji t :

Tabel 6

Hasil Uji t

\begin{tabular}{|c|c|c|c|c|c|c|}
\hline \multicolumn{7}{|c|}{ Coefficients $^{a}$} \\
\hline & & \multicolumn{2}{|c|}{ Unstandardized Coefficients } & $\begin{array}{l}\text { Standardized } \\
\text { Coefficients }\end{array}$ & \multirow[b]{2}{*}{$\mathrm{t}$} & \multirow[b]{2}{*}{ Sig. } \\
\hline \multicolumn{2}{|c|}{ Model } & B & Std. Error & Beta & & \\
\hline \multirow[t]{4}{*}{1} & (Constant) & 4049.347 & 964.308 & & 4.199 & .000 \\
\hline & X1_Kurs & -.064 & .058 & -.216 & -1.107 & .272 \\
\hline & X2_Harga Emas & .000 & .001 & -.036 & -.316 & .752 \\
\hline & X3_Indeks_Dow_Jones & .079 & .023 & .577 & 3.478 & .001 \\
\hline
\end{tabular}

Sumber : Data diolah 2020

Uji t dalam regresi linier berganda dimaksudkan untuk menguji seberapa jauh pengaruh satu variabel penjelas secara individual atau parsial dalam menerangkan variasi variabel terikatnya. Hasil pengujian uji t bisa dilihat dari tabel Coefficients.

\section{Uji Koefisien Determinasi $\left(\mathbf{R}^{2}\right)$}

Berikut ini merupakan hasil uji koefisien determinasi $\left(\mathrm{R}^{2}\right)$ :

Tabel 7

Hasil Uji $\mathbf{R}^{2}$

\begin{tabular}{l}
\begin{tabular}{|l|c|c|c|c|c|}
\hline \multicolumn{7}{|c|}{ Model Summary $^{\text {bo }}$} \\
\hline del & $\mathrm{R}$ & $\begin{array}{c}\mathrm{R} \\
\text { Square }\end{array}$ & $\begin{array}{c}\text { Adjusted R } \\
\text { Square }\end{array}$ & $\begin{array}{c}\text { Std. Error of } \\
\text { the Estimate }\end{array}$ & $\begin{array}{c}\text { Durbin- } \\
\text { Watson }\end{array}$ \\
\hline 1 & $.690^{\mathrm{a}}$ & .476 & .455 & 75.64927 & 1.929 \\
\hline
\end{tabular} \\
a. Predictors: (Constant), Lag_X3_Indeks_Dow_Jones, Lag_X2_Harga_Emas, \\
Lag_X1_Kurs \\
b. Dependent Variable: Lag_Y_Indeks_Harga_Saham_Gabungan \\
\hline
\end{tabular}

Sumber : Data diolah 2020

Dari hasil pengolahan data menunjukan Adjusted $R$ Square sebesar 0,455 atau 45,5\%. Angka tersebut memberikan arti bahwa perubahan Indeks Harga Saham Gabungan (IHSG) dipengaruhi oleh Kurs, Harga Emas, dan Indeks Dow Jones sebesar 45,5\% dan sisanya 54,5\% dipengaruhi oleh variable lain yang tidak dimasukan dalam model ini seperti Inflasi, Suku Bunga (BI Rate), tingkat Produk Domestik Bruto (PDB) dan factor Lainnya.

\section{ANALISIS PEMBAHASAN}

\section{Analisis Pengaruh Kurs Rupiah (X1) terhadap IHSG periode Maret - Juli 2020}

Penelitian ini menunjukan kurs Rupiah tidak berpengaruh terhadap IHSG pada periode MaretJuli 2020. dengan hasil signifikansi uji t sebesar 0,272 yang berarti bahwa 0,272>0,05 maka H2 ditolak. Hal ini berarti tidak konsisten dengan teori yang mengatakan Kurs/nilai tukar berpengaruh terhadap Indeks Harga Saham Gabungan.

Berdasarkan teori kurs valuta asing atau kurs mata uang asing menunjukkan harga atau nilai mata uang sesuatu negara dinyatakan dalam nilai mata uang negara lain. Naik turunnya nilai kurs valuta asing menjadi salah satu dampak bagi keseluruhan dunia usaha, kurs valuta asing mencerminkan keseimbangan permintaan dan penawaran mata uang negara terhadap mata uang asing. 
Berdasarkan hasil penelitian variable independen (X1) yakni Kurs secara parsial tidak berpengaruh terhadap IHSG, hasil tersebut konsisten dengan penelitian yang dilakukan oleh Rihfenti Ernayanti dan Mursalin (2015) karena memperoleh hasil penelitian Kurs tidak berpengaruh secara parsial terhadap IHSG. Sedangkan hasil penelitian tidak konsisten dengan yang diperoleh Reshinta Candra Gumilang (2014) Karena memperoleh hasil Kurs berpengaruh secara parsial terhadap IHSG.

\section{Analisi Pengaruh Harga Emas terhadap IHSG (Maret - Juli 2020)}

Hasil penelitian ini, harga emas tidak berpengaruh terhadap pergerakan Indeks Harga Saham Gabungan pada periode tersebut. Hasil Uji Statistik Penelitian menunjukan bahwa variable Harga Emas tidak berpegaruh terhadap Indeks Harga Saham Gabungan di Bursa Efek Indonesia periode Maret - Juli 2020 , dengan signifikansi uji t sebesar 0,752 yang berarti bahwa $0,752>0,05$

Berdasarkan teori dikatakan bahwa Harga emas juga ikut yang mempengaruhi Pasar Modal atau IHSG, karena emas merupakan salah satu alternatif dalam berinvestasi. salah satu investasi yang cenderung bebas risiko adalah emas.Hasil penelitian ini tidak konsisten dengan teori. Tetapi Hasil penelitian ini konsisten dengan penelitian yang dilakukan oleh Abdul Basit (2019) karena memperoleh hasil penelitian Harga Emas tidak berpengaruh terhadap IHSG. Sedangkan hasil penelitian tidak konsisten dengan yang diperoleh Agus Suharto dan MG. Kentris Indarti (2014) karena memperoleh hasil Harga Emas berpengaruh terhadap IHSG. Kongres Amerika Serikat (AS) mengesahkan stimulus senilai US\$ 500 miliar untuk tagihan alat-alat kesehatan dan tunjangan tenaga kerja. Pasalnya jumlah pengangguran di AS telah melonjak hingga 26,5 juta

\section{Pengaruh Indeks Dow Jones (X3) terhadap IHSG}

Hasil Penelitian menunjukan bahwa variable Indeks Dow Jones berpengaruh positif terhadap Indeks Harga Saham Gabungan di Bursa Efek Indonesia periode Maret - Juli 2020 dengan signifikansi uji t sebesar 0,001 yang berarti bahwa $0,001<0,05$ maka $\mathrm{H} 4$ diterima.

Pasar modal Indonesia dipengaruhi pergerakan pasar modal lain terutama dari negara yang memiliki perekonomian yang kuat.

Dengan demikian hal ini sesuai teori. Hal tersebut menunjukan bahwa kondisi perekonomian Negara maju akan mempengaruhi perekonimian Negara berkembang. Pengaruh Indeks Dow Jones terhadap IHSG adalah positif atau berbanding lurus dimana jika Indeks Dow Jones naik, maka IHSG pun naik dan begitu juga sebaliknya. Hasil penelitian ini konsisten dengan penelitian yang dilakukan oleh Rihfenti Ernayanti dan Mursalin (2015) karena memperoleh hasil penelitian Indeks Dow Jones berpengaruh secara parsial terhadap IHSG. Sedangkan hasil penelitian tidak konsisten yang diperoleh Yudhistira Ardana, Rita Irviani, Wulandar (2018) karena memperoleh hasil Indeks Dow Jones secara parsial tidak berpengaruh terhadap IHSG.

\section{KESIMPULAN}

Dari hasil penelitian ditemukan bahwa secara simultan Makro Ekonomi di wakili oleh Kurs,Harga Komunitas diwakili dengan harga Emas dunia,Kinerja Pasar Modal Amerika diwakili dengan Indeks Dow Jones mempengaruhi Pasar Modal Indonesia diwakili dengan IHSG. Secara parsial hanya Indeks Dow Jones yang mempengaruhi Indeks Harga Saham Gabungan ,sedangkan kurs rupiah /Dollar, dan Harga emas dunia tidak berpengaruh terhadap Indeks selama periode pengamatan bulan Maret sampai dengan Juli 2020. Pada awal bulan maret 2020 ditemukannya Covid 19 di Indonesia dan dengan cepat menyebar di seluruh Indonesia yang menyebabkan investor panik dan menjual saham secara besar-besaran sehingga menurunnya harga saham yang menyebabkan kinerja pasar Modal Indonesia menurun drastis. Tekanan tidak hanya terjadi pada pasar modal Indonesia tetapi terhadap pasar modal dunia hal ini disebabkan oleh sentimen negatif 
yang terus menekan kinerja ekonomi secara global serta diumumkannya Virus Corona sebagai pandemi dunia oleh $\mathrm{WHO}$, selain itu adanya perang harga minyak dunia dan penurunan suku bunga oleh Bank Sentral Amerika Serikat Federal Reserve (The Fed) dengan tujuan mengatasi krisis global namun usaha ini tidak berhasil. Melonjaknya Harga emas dunia bukan karena investor menjual sahamnya dan mengalihkan investasinya ke emas tetapi karena adanya kebijakan pemerintah Amerika untuk mengatasi pandemi Covid 19 dengan mengesahkan stimulus senilai US\$500 milyar untuk tagihan alat-alat kesehatan dan tunjangan tenaga kerja disebabkan tingkat pengangguran yang tinggi hingga 26,5 juta orang sejak pandemi.

\section{REFERENSI :}

Brigham dan Huston. 2014. Dasar-dasar Manajemen Keuangan. Buku Dua. Edisi kesebelas. Alih Bahasa Ali Akbar Yuianto. Jakarta: Salemba Empat, Jakarta.

Fahmi, Irham. 2014. Manajemen Keuangan Perusahaan dan Pasar Modal.Penerbit: Mitra Wacana Media

Fransiskus Paulis Paskalis abi. 2016. Semakin Dekat Dengan Pasar Modal Indonesia. Edisi kesatu Penerbit Deepublish. Yogyakarta.

Rochmat Aldy Purnomo. 2017. Analisis Statistik Ekonomi dan Bisnis dengan SPSS. Cetakan Ketiga. Penerbit WADE Group. Ponorogo

Abdul Halim. 2015. Analisis Investasi di Aset Keuangan. Penerbit Mitra Wacana Media. Jakarta.

Anwar Sanusi. 2017. Metodologi Penelitian Bisnis. Penerbit Salemba Empat. Jakarta

Jul Fahmi Salim, 2017 "Pengaruh Faktor Dalam dan Luar Negeri Terhadap Indeks

Sadono Sukirno. 2015."Makroekonomi Teori Pengantar".PT Raja Grafindo Persada, Jakarta.

Samsul, Mohamad. (2015). Pasar Modal \& Manajemen Portofolio, Edisi 2. Jakarta : Erlangga.

Sukamulja,Sukmawati,2017."Pengantar Pemodelan Keuangan dan Analisis Pasar Modal", Yogyakarta:Penerbit ANDI.

Tjipto Darmadji, Hendy M. Fakhruddin. 2011. Pasar Modal Di Indonesia. Edisi Ketiga. Jakarta : Penerbit Salemba Empat.

Harga Saham Gabungan(IHSG) di Indonesia”Jurnal ekonomi dan kebijakan public Indonesia E-ISSN $: 2549-8355$

Riski Nurida Rahmawati. 2016. “Analisis Pengaruh Interdependence Indeks Harga Saham di Bursa Global terhadap Indeks Harga Saham Gabungan di BEI"

Widoatmodjo, Sawidji. 2015. Pengetahuan Pasar Modal Untuk Konteks Indonesia.Penerbit : Kompas Gramedia. Jakarta

Sumber Jurnal :

Anik Yuesti 1, Ni Wayan Rustiarini 2, Ni Nyoman Ayu Suryandari 3,Financial Literacy In The Covid-19 Pandemic: Pressure Conditions In Indonesia , 1 (September) http://doi.org/10.9770/jesi.2020.8.1(59)

Budi Sutanto .2013. "Analisis Pengaruh Ekonomi Makro, Indeks Dow Jones, dan Indeks Nikkei 225 terhadap Indeks Harga Saham Gabungan di BEI Periode 2007-2011"

Habib Muhammad Husnul .2017. "Analisis Pengaruh Inflasi, Kurs, Porduk Domestik Bruto dan Harga Emas Dunia terhadap Indeks Harga Saham Gabungan Indonesia periode 2008-2016"

Reshinta Candra Gumilang .2014. "Pengaruh Variabel Makro Ekonomi, Harga Emas dan Harga Minyak Dunia terhadap Indeks Harga Saham Gabungan pada Bursa Efek Indonesia periode 20092013"

Kasyfurrohman Ali. 2012. Analisis Pengaruh Variabel Ekonomi terhadap $\quad$ Reksadana $\quad$ Syariah di Indonesia.

Manan. 2012. Hukum Ekonomi Syariah: Dalam Perspektif Kewenangan Peradilan Agama. Kencana, Jakarta. 